\title{
The Assessment of Mongolian Sovereign Funds
}

\author{
Bayarjargal Turgenbayar \\ Master of Science in International Relations, \\ Diplomat, Ministry of Foreign Affairs, Ulaanbaatar, MONGOLIA \\ tbaaraa@gmail.com
}

\begin{abstract}
Mongolia is the one of the resource rich countries facing natural resource curse, relatively transparent with satisfactory resource governance. Some would argue establishing sovereign wealth fund (SWF) is beneficial those countries with natural resource curse while others against it. Mongolian government established several SWFs and namely Human Development Fund (HDF-afterwards renamed as Future Heritage Fund) and Fiscal Stability Fund (FSF) but still facing to create an efficient SWF.

Some scholars would agree that it is important to find causal relations between management of SWF and its efficiency to establish an efficient and beneficial SWFs. There are several ways to reveal such relations, however, most research centres are using following major methods such as Resource Governance Index (RGI), Truman scoreboard and LinaburgMaduell Transparency Index (LMTI) and Santiago Principles. This paper is examined Mongolian SWFs namely Human Development Fund (HDF) and Fiscal Stability Fund (FSF) using some of these methods.
\end{abstract}

\section{Introduction}

In 2018, according to Sovereign the structure of the Norway's SWF, the Wealth Fund Institute survey, globally first SWF's operation was not successful 80 SWFs of 49 countries accumulated at all, government experienced failure USD7.9 trillion savings (SWFI, in late 1950's when the government Sovereign Wealth Fund Institute, 2018). expenditure grew fast and revenue failed Among these savings the Norwegian to keep up. Maybe it is nanve to think Government Pension Fund counted alone that, once established, a fund's structure USD1.035 trillion which is around 270 should be immutable to political forces percent of Norway's GDP. The SWFs are or changing circumstances (Truman E. , increase their assets not only from natural A Blueprint for Sovereign Wealth Fund resource revenues, but also of a solution Best Practices, 2009, p. 437). This is an whereby government revenue channelled invitation either to illegal activity or to straight into the fund and invested overturning the structure completely. abroad (Lie, 2018, p. 284). Regarding But, Norway has altered the structure Received: 05 October, $2020 \quad$ Accepted: 30 October, 2020 
and orientation of its SWF several times since it was first established in 1990, whilst a number of SWFs have collapsed or have been liquidated in part because of they were excessively rigid (Truman E. , A Blueprint for Sovereign Wealth Fund Best Practices, 2009, p. 437). This statement shows that SWFs better be flexible with their structure, but the process of changing structure should be straightforward, also should initially grounded in relevant law.

On contrary, some governments failed to establish a successful SWF such as Azerbaijan State Oil Fund (SOFAZ), Trinidad and Tobago's Heritage and Stabilization Fund and Venezuela's Macroeconomic Stabilization Fund. The government of Azerbaijan served to undermine public financial management system, financed railway between Azerbaijan, Georgia and Turkey directly from SOFAZ (Bauer A. , Managing the public trust: How to make natural resource funds work for citizens, 2014, p. 16). It is obvious that every SWF has experienced different challenges because of diverse economic situation, political regime and institutional structure and other socio-economic factors. From the existing SWFs, some are funded from fiscal surpluses or foreign exchange reserves, while others are funded from borrowings from the market. Almost half of the SWFs operate by separate entities, while the rest consist of a dependent entity within Ministry of Finance or the Central Bank (Ahmadov, Tsani, \& Aslani, 2011, p. 10). Therefore, it is obvious that SWFs are vary in their nature, objectives, structure, operations and ownership which makes difficult to crystalize the image of SWFs.

Mongolia is one of those countries struggling to establish an effective mechanism to function as an SWF by accumulating portions of mining revenues. The World Bank has been supporting the Mongolian government to improve the design of their SWF, and advisors are working with the government have proposed three SWFs (Robbins \& Smith, 2014, p. 3). These funds are: Fiscal Stability Fund, which was established concurrently with the Fiscal Stability Law ${ }^{1}$ (FSL) in 2010, to stabilize volatile mineral revenue an smooth the government's revenue stream; Future Heritage Fund, with a long-term investment horizon, to convert a portion of Mongolia's mineral wealth to financial wealth for the benefit of future generations; Pension Reserve Fund, with a long-term investment horizon, which serves as a financial reserve to guarantee public obligations. The SWF is not a new terminology for the government of Mongolia, prior the government established funds namely the Mongolia Development Fund (MDF) in accordance with the Mongolia Development Fund Law $^{2}$ in 2007, and Human Development Fund (HDF) in accordance with the Human Development Fund Law (HDFL) in 2009. Unfortunately, the government's over optimistic about its projection and realisation of election promises entailed the HDF to face a shortage of asset and incurred loans. As a result, in 2016, the parliament passed new Future Heritage Fund Law (FHFL) and

1 It also named as Fiscal Stability Law

2 http://legalinfo.mn/law/details/7102 
abolished the HDFL. The FHF committed to be active upon clearing all outstanding debts of the former HDF, which were estimated to be approximately MNT947 billion (about USD384 million ${ }^{3}$ ) as of 31 December 2015 (Lee S. M., 2017, p. 2). In accordance with the law, assets of the FHF will be managed by an investment management institution established pursuant to the FHFL.

The government adopted the FSL in assistance of World Bank and International Monetary Fund (IMF) in 2011. As a result, the FSF was established in accordance with FSL with MNT241 billion (about USD97.8 million ${ }^{4}$ ) assets. The government proposed to increase fund's asset MNT1.4 trillion (about USD5.8 million) by 2017, but in reality, the FSF was just over MNT326 billion (about USD132 million). Overall, the FSF asset shows (graph 1) that the fund functioned not effective as it proposed from government.

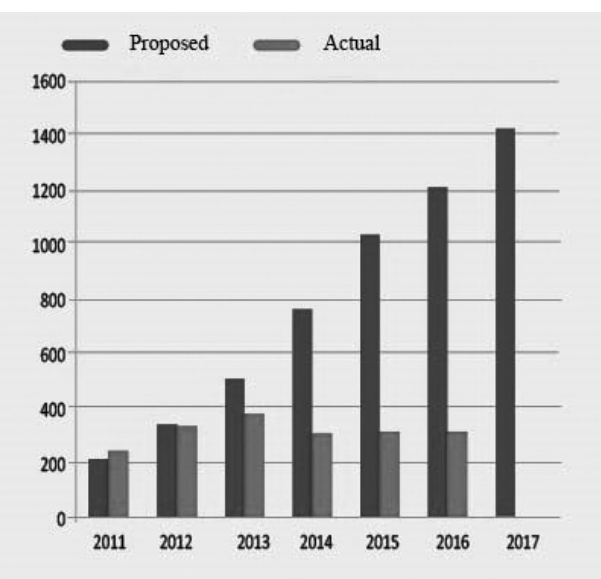

Graph 1. The FSF: Proposed and actual assets (MNT billion) (Tuvshin, 2017)
The above-mentioned situation regarding the HDF and FSF entails to the question, whether government should establish the SWF, why the government of Mongolia cannot run the SWF as efficient as proposed? A simple answer regarding the necessity of establishing the SWF, was given by Rolando Ossowski, a former assistant director at Fiscal Affairs Department of the IMF. He unfolded four reasons why Mongolian government should establish SWF during the conference in Ulaanbaatar, 2013 (Lee \& Smith, 2013). First, natural resource revenues are volatile and uncertain. Global prices can change to great extent, without warning and are almost impossible to project reliably. Second, natural resources run out; they are exhaustible. The benefits must be made to last by transferring some (and not all) for future generations. Third, Mongolia will be selling most of its copper, coal, oil and other minerals abroad. This has implications for the domestic economy in terms of how the non-mining sector competes and in terms of macroeconomic stability. Fourth, the exploitation of natural resources can be a source of corruption and inefficiency. Mongolia needs to deliver value for money when investing and spending tax payers' and mining revenues. Since 2007, the Mongolian government has not established an effective SWF as proposed to public, but the government still encouraging to establish a new SWF. In January 2018, the Mongolian Minister of Mines and Heavy Industry D.

3 MNT947 billion equals USD384 million due to exchange rate of Central Bank of Mongolia. (USD1 = MNT2464 in 27 July, 2018)

4 MNT241 billion equals USD97.8 million (USD1 = MNT2464; 27 July, 2018) 
Sumiyabazar has stated that "Commodity prices at global market increased and have been projected to remain at this level for next 3-5 years. Hence, a SWF should be created within 2018" (MBD, 2018), and he wishes to manage the new SWF by independent state-owned enterprise (Dorjdari Namkhaijantsan, 2018).

\section{Definition and classification of SWFs}

The idiom SWF was first used by Andrew Rozanov (Who holds the wealth of nations, 2005), later Edwin Truman (Sovereign Wealth Funds: Threat or Salvation?, 2010) defined the sovereign wealth fund in broad meaning, as "a large pools of government-owned funds that are invested in whole or in part outside their home country." Similarly, Castelli and Scacciavillani (The New Economics of Sovereign Wealth Funds, 2012) stated as "publicly owned investment vehicles with a mandate to transfer wealth to future generations by investing in an international portfolio of securities and assets, including companies." They both excluded investment vehicles primarily geared toward domestic development, such as state-owned enterprises or national development banks and entities financed primarily through transfers of central bank reserves. Generally, the SWF is a state-owned investment fund or entity created by the general government for macroeconomic purposes (IWG, Sovereign Wealth Funds: Generally
Accepted Principles and Practices "Santiago Principles", 2008) that is commonly established from balance of payment surpluses, official foreign currency operations, the proceeds of privatizations, governmental transfer payments, fiscal surpluses, and receipts resulting from resource exports (SWFI, Sovereign Wealth Fund Institute, 2018). This is the ideal definition to determine the main characters of SWFs.

Sovereign wealth funds are usually distinguished by their policy objectives and consequent asset allocation. The IMF classified SWFs into five types according to their purposes and roles. These are stabilization funds, savings funds ${ }^{5}$, development funds, pension reserve funds, and reserve investment funds. The stabilization funds set up to insulate the budget and economy from commodity price volatility and external shocks ${ }^{6}$; savings funds intended to share wealth across generations by transforming non-renewable assets into diversified financial assets ${ }^{7}$; development funds established to allocate resources to priority socio-economic projects, such as infrastructure ${ }^{8}$; pension reserve fund set up to meet identified outflows in the future with respect to pensionrelated contingent-type liabilities on the government's balance sheet ${ }^{9}$; and reserve investment funds intended to reduce the negative carry cost of holding reserves or to earn a higher return on ample reserves, while the assets in the funds are

5 ISWF also called Savings or Future Generations Funds.

6 Economic and Social Stabilization Fund (Chile), Oil Stabilization Fund (Russia, Iran, Timor-Leste)

7 National wealth fund (Abu Dhabi Investment Authority, Libya, Russia)

8 National Development Fund (United Arab Emirates, Iran)

9 National Pension Fund (Norway, Australia, New Zealand, Ireland) 
still counted as reserves ${ }^{10}$ (Al-Hassan, Papaioannou, Skancke, \& Sung, 2013, pp. 4-5). It is also important to distinguish SWFs from other extrabudgetary funds.

\section{Extrabudgetary funds (EBFs)}

Governments often exclude some revenues, expenditures or financing from their annual budget laws, using separate banking or institutional arrangements called extrabudgetary funds to finance particular items (Bauer A. , 2014, p. 13). In technical note of IMF prepared by Allen and Radev (Extrabudgetary Funds, 2010) claims that extrabudgetary transactions are the broadest concept and include all revenues, expenditures, and financing that are excluded from the budget. Extrabudgetary accounts are the bank arrangements into which extrabudgetary revenues and expenditures are paid in and disbursed. Therefore, EBFs can be broadly characterized as resources managed directly by or indirectly by administrative branches of the government outside the normal budgetary process, and come from three main sources including charges for government provided goods and services (i.e. housing, medical care, education, water); administration fees (i.e. passports, driver licenses); and income from state assets (Wong, 1999).

Mongolia has established SWFs or EBFs?

According to law of Mongolia Development Fund (2007) the main financial sources of the MDF are income tax increase, budget profit, non-spent asset of risk fund. The fund will locate in state fund and allowed to use as a compensation for deficit of budget revenue due to force majeure, support children and family and invest small and medium sized business entrepreneurs responsible to contribute economic growth. Due to above definitions, the MDF is more fit in EBF rather than SWF. In contrast, the HDF and FSF were established as a successor of MDF to accumulate asset from mineral revenue and allocate the wealth to Mongolian citizens equally, as well as provide an economic stability. According to law of HDF, the fund was located in special account established in Central Bank of Mongolia and increase saving by accumulating mineral revenue (dividend and royalty) and income from investment. The characteristics and structure of the HDF corresponded the definition of SWF, specifically saving fund which is intended to share wealth across generations by transforming non-renewable assets into diversified financial assets. The FHF as successor the HDF has established to deliver natural resource wealth to future generation. The law of FHF stated more specifically about accumulating revenue, structure of institution and fund management.

The FSF is established in 2010 in order to reduce volatility in the budget by accumulating the excess revenues from the structural basis revenue and overcome economic shocks. Due to its objective, the FSF is mixture of stability and savings SWF. According to the definitions, the HDF, FHF and FSF are considered to be SWFs.

10 National Investment Corporation (China, South Korea, Singapore) 
Key factors effecting on SWFs: Why resource curse is matter?

Resource curse is the term used to describe the failure of resource-rich countries to benefit from their natural wealth (Humphreys, 2007). The termresource curse was first used in print by economic geographer Richard Auty in 1993 (Auty, 2002). Scholars have different view and studies concerning the resource curse effects, some studies found no evidence, or mixed evidence, of certain resource curse effects. For example, Alexeev and Conraad (The Elusive Curse of Oil, 2009) refuted that large endowments of oil or minerals slow long-term economic growth, and suggested that natural resources enhance long-term economic growth. Similarly, Brunnschweiler and Bulte (The resource curse revisited and revised: A tale of paradoxes and red herrings, 2008) concluded that resource abundance positively affects economic growth and institutional quality. Bhattacharyya \& Hodler (Natural resources, democracy and corruption, 2010) studied how natural resources can feed corruption and effect depends on the quality of the democratic institutions and found resource windfalls encourage government to engage rentseeking which tend to be corrupted, however, democracy mitigate this process. Michael Ross (What have we learned about the resource curse?, 2015) claims that higher levels of petroleum income lead to more durable authoritarian rulers and regimes; more petroleum income increases the likelihood of certain types of government corruption; and high levels of resource wealth tend to trigger or sustain conflict particularly in low- and middle-income countries. Overall, rich natural resource can undermine good governance and the quality of institution in a society in developing countries or countries with weak political institutional structure. In other words, mix of weak institutions and resource abundance causes the resource curse (Mehlum, Moene, \& Torvik, 2006).

One of the main key roles of SWF is to mitigate negative economic and political consequences of natural resource wealth, which often lumped together as the resource curse. Jedrzej Frynas (Sovereign Wealth Funds and the Resource Curse: Resource Funds and Governance in Resource-Rich Countries, 2007) conducted a research hypothesizing that SWFs could mitigate recourse curse effects through improving governance and reducing price volatility. Mongolia is one of the countries suffering resource curse, however, there is no distinct measurement or definition whether country is cursed or blessed. In other words, Mongolia is rich of natural resource country, but its economy and countries development are below compared to other developing countries without natural resource.

What are key factors establishing a successful SWF?

Tsani et al., (Governance, transparency and accountability in Sovereign Wealth Funds: Remarks on the assessment, rankings and benchmarks to date, 2010) claim that strong governance structure, transparency and accountability remain a key factor of success for the SWFs. In other words, strong governance and adequate provision of transparency 
and accountability can foster success in combating political misuse, rent-seeking and corruption in SWF operations. NRGI and CCSI (Managing the public trust: How to make natural resource funds work for citizens, 2014) surveyed several SWFs and found a vital key elements of good fund governance. First key element is setting a single or multiple fund objective which should be clearly stated in government policy, regulation, legislation or even in the constitution. Second, creating an effective institutional governance including effective organizational structure and management. Third, establishing appropriate fiscal rules necessary given the finite and destabilizing nature of oil, gas and mineral revenues, and discourage overspending and waste by limiting a government's ability to grow expenditures too quickly. Fourth, setting clear investment constraints to prevent "principal-agent" problems, wherein the managers of government assets act in accordance with personal rather than public interests, are a common source of conflict of interest. Fifth, making extensive information on fund operations public by transparency - the degree of information is available to outsiders that enables them to have informed voice in decisions and/or to assess the decision made by insiders. Sixth, establishing strong independent oversight/audition to identify noncompliance with rules, waste, fraud, mismanagement, and suggest or enforce corrections (Florini, 2007, p. 5).

Currently, there are four well known methods namely SantiagoPrinciples ${ }^{11}$, Truman scoreboard,
LMTI and Resource Governance Index measuring resource governance, transparency and accountability. SWFs generally accepted principles and practices (GAPP) or Santiago-Principles' main purpose is to identify a framework of generally accepted principles and practices that properly appropriate governance, accountability arrangements and investment practices. The GAPP is a voluntary based principles and practices covers three key areas: i) legal framework, objectives, and coordination with macroeconomic policies; ii) institutional framework and governance structure; and iii) investment and risk management framework (IWG, Sovereign Wealth Funds: Generally Accepted Principles and Practices "Santiago Principles", 2008, p. 5) that members of International Working Group (IWG) support and either have implemented. The GAPP has 24 principles (appendix 1) which are evaluating SWFs of member countries of International Forum of SWFs (IFSWF) to emphasise appropriate governance, accountability arrangements and prudent, commercial investment activity. The significance of the Santiago Principles is examining SWFs based on case studies.

Edwin Truman (A Scoreboard for Sovereign Wealth Funds, 2007) presented the first scoreboard at the Conference on China's Exchange rate policy to evaluate each individual SWFs structure - SWFs objectives, fiscal treatment, and whether it is separate from the country's international reserve; governance - roles of the government and the managers, whether the fund follows guidelines

11 Produced by International Working Group of the IMF 
for corporate responsibility and ethical investment behaviour; transparency and accountability -investment strategy, investment activities, reporting and audits; and behaviour - managing its portfolio and in the use of leverage and derivate (Truman E. , A Blueprint for Sovereign Wealth Fund Best Practices, 2009). The scoreboard evaluates the SWFs which relies on asking simple yes/no questions within four categories, including structure of the fund, governance of the fund, accountability and transparency and behaviour of the fund ${ }^{12}$. From the Truman scoreboard (appendix 2) he found that there is a link between resource fund governance ${ }^{13}$ and societal governance ${ }^{14}$, when country's societal governance is high, the resource governance tends to be high, but except some countries such as Qatar, Oman ${ }^{15}$, Azerbaijan, Timor-Leste, Trinidad and Tobago, and Kazakhstan ${ }^{16}$, they are in reverse relationship. For example, Azerbaijan's SOFAZ fund considered one of high transparent SWFs, but operates in a very badly governed society including the lack of withdrawal rules, lack of parliamentary oversight, highly corrupted and opaque, lack of independent media. Comparing the indicators of Truman Scoreboard researcher concluded that effective societal institutions such as sound fiscal rules, the quality of government budget documentation, a free civil society or independent media appear to be a prerequisite for minimizing resource curse. In contrast, establishment of a resource fund may either have no effect on mitigating resource curse effects, or at best may have a moderating effect. Similarly, the Linaburg-Maduell Transparency Index evaluate SWFs by giving scores answering in 10 questions. This method is produced by SWFI based on publicly open resource.

In summary, the Truman scoreboard and Linaburg-Maduell Transparency Index are mostly concentrated on transparency of SWF. The assessing of questions tended to ask whether the information is publicly open or not and ranking by scores. The drawback of both scoreboards is unable to evaluate those SWFs' information which is confidential or published in their own language. In contrast, the GAPP or Santiago-Principles evaluating SWFs based on information provided from local authorities, which is more reliable but sometimes obscuring the real cause of inefficient governance of SWF. For example, Azerbaijan's SOFAZ SWF's score result shows that transparency and accountability is increasing, but in reality, the efficiency of SWF is not good, and the none of the Truman scoreboard, Linaburg-Maduell Transparency Index, Santiago-Principles' score does not display that. The RGI only method illustrates that Azerbaijan SOFAZ resource governance is weak. Therefore, the case study and analyze of local

12 There are 33 elements/questions evaluating SWFs, if answer is yes scored it as 1, if no score. Also, answers available partial scores of $0.25,0.50$, and 0.75 (Bagnall \& Truman, 2013). All these 33 individual elements equally weighted and translated into a 100-point scale.

13 Representing by the country's resource governance index in Truman Scoreboard

14 Representing by country's political stability index, rule of law index, and regulatory quality index in Truman Scoreboard

15 Qatar and Oman have high score in societal governance but considerably low in resource fund governance

16 In those countries high score in resource governance but considerably lower scores for societal governance 


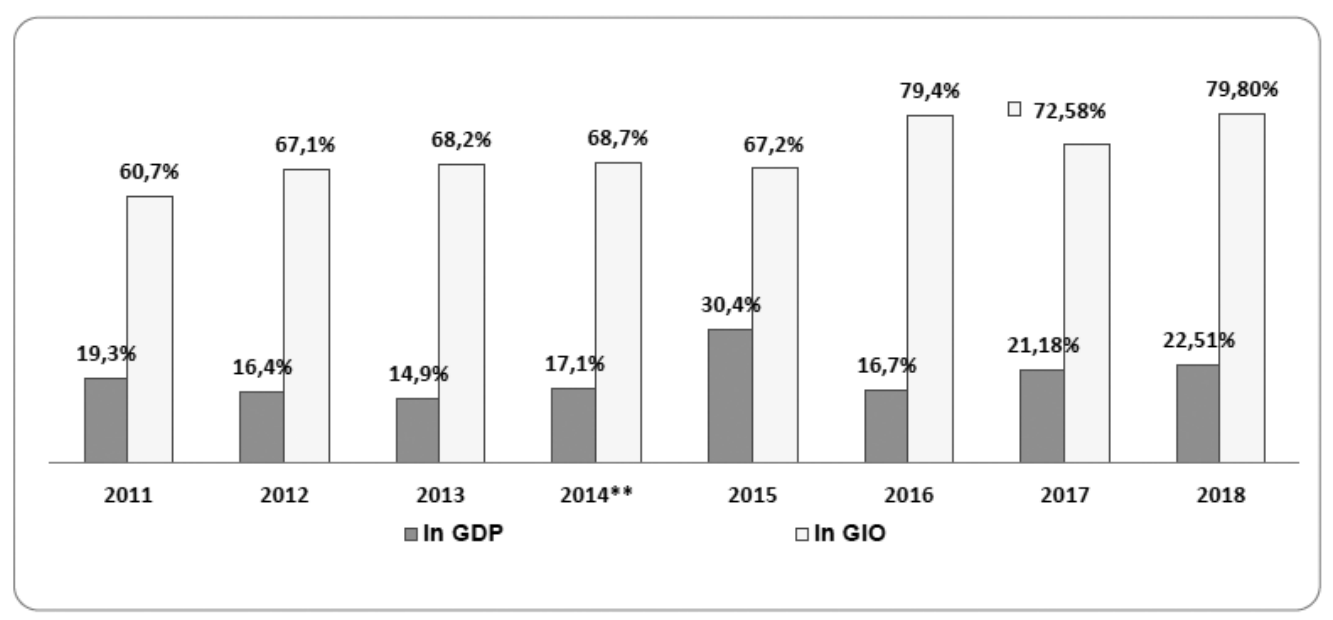

Graph 2. The role of mining sector in the national economy. Green column represents mineral rents of GDP, yellow column represents mining rate in industry.

official information could exhibit the real efficiency of SWF.

Economic and natural resource overview of Mongolia

Mongolia is a landlocked unitary sovereign state sandwiched between Russia and China. The $18^{\text {th }}$ largest country in the world, population totals about 3.2 million. Through the early 1990's Mongolia's economy contracted following the loss of support from the Soviet Union. Mongolia enacted the Minerals Law in 1997, which helped attract private investment to the sector, and through 2002 Mongolia's Ministry of Mining issued almost 3,000 exploration licenses, covering almost 30 percent of the country's territory (Robbins \& Smith, 2014). Since, the Foreign Direct Investment (FDI) increased significantly in extracting mineral resource sector. Mongolia has abundant mineral deposits of uranium, copper, gold, coal, molybdenum, fluorspar, tin, and tungsten
(Thomas, 2012). According to first half year report of Mineral Resource and Petroleum Authority (MRPA) in 2018, in state's integrated registration list recorded 65437,9 thousand tons gold (rock) ore, 29883 thousand tons of copper ore, and 9662 thousand tons of coal (appendix $3)$. The average mineral rents of GDP are $20 \%$, and the mining sector take alone nearly $80 \%$ of all industry which is increase about 20\% since 2011 (graph 2). From giving information it can be seen the mining industry is dominant sector in Mongolian economy, and its GDP significantly reliant on natural resource.

Regarding the increase of copper prices globally and new gold production the economic growth averaged nearly $9 \%$ per year in 2004-2008. In early 2009 , the IMF reached a $\$ 236$ million Stand-by Arrangement with Mongolia and it emerged from the crisis with a stronger banking sector and better fiscal management (IMF, 2010). In October 2009, Mongolia passed long- 
awaited legislation on an investment agreement to develop the Oyu Tolgoi (OT) mine, among the world's largest untapped copper-gold deposits (CIA, 2017). Although the agreement to resume a delayed $\$ 5$ billion underground expansion at Oyu Tolgoi was signed by the government and Rio Tinto in May 2015, ending a row that scared off foreign investors, FDI did not increase as expected (BTI, 2017). Mongolia has agreed with the International Monetary Fund and other partners for a \$5.5 billion economic stabilization package, according to a statement from the IMF in May 2017, which is expected to improve Mongolia's long-term fiscal and economic stability as long as Ulaanbaatar can advance the agreement's difficult contingent reforms, such as consolidating the government's offbalance sheet liabilities and rehabilitating the Mongolian banking sector.

The economic and natural resource overview of Mongolia shows that Mongolia is one the rich and reliant on natural resource countries. This statement illustrates that Mongolia is worth to establish SWFs, but previous unsuccessful established SWFs are frustrating trust of public whether SWF is beneficial for Mongolian economy.

\section{The Human Development Fund}

The Parliament adopted Law of Human Development Fund (HDF) in 2009 to implement allocating of MNT1.5 million (about USD1054 ${ }^{17}$ ) for every citizen from the prospective mining riches natural wealth according to Action Program of the Government of Mongolia for 2008-2012. Revenues from mineral deposits planned to be distributed to citizens in cash, health and social insurance withdrawals, tuition and residential payments. In other words, the government had an obligation accumulate at least USD2.8 billion (the population of Mongolia in 2009 was 2.7 million and the asset have to increase in regard of number of population) asset through the HDF. As a result, the government decided to allocate MNT500 thousand (about USD358 ${ }^{18}$ ) in cash for every citizen between 2010 and 2012 ${ }^{19}$, and rest of MNT1 million allocate by providing share of "Erdenes Tavan tolgoi" ${ }^{20}$ state owned company ${ }^{21}$. In 2012, the government limited the number of citizens who available to acquire shares ${ }^{22}$ and counted totally 2.834 .837 citizens. The limitation was made by date of birth and the government registered Mongolian citizens those who born before 31 March 2011. It was an ideal decision not to increase the obligation of HDF.

In 2012, the government have been

17 MNT1.5 million equals USD1054 due to exchange rate of Central Bank of Mongolia. (USD1 = MNT1423.74 in 05 November 2009) But due to exchange rate MNT1.5 now equals USD608. (USD1=MNT2467.76 in 20 August 2018)

18 MNT500 thousand equals USD358, exchange rate of Central Bank of Mongolia (USD1 = MNT1397.28 in 1st December 2012)

$1984^{\text {th }}$ resolution of the Government, 2010.

20 "Erdenes-Tavan Tolgoi" JSC established with objective to implement the policy of putting deposit of strategic importance into economic circulation, conducting mining operation and implementing infrastructure projects in accordance with the Law on Minerals (http://www.erdenestt.mn/)

$2157^{\text {th }}$ resolution of the Parliament, 2012.

$22116^{\text {th }}$ resolution of the Government, 2012. 


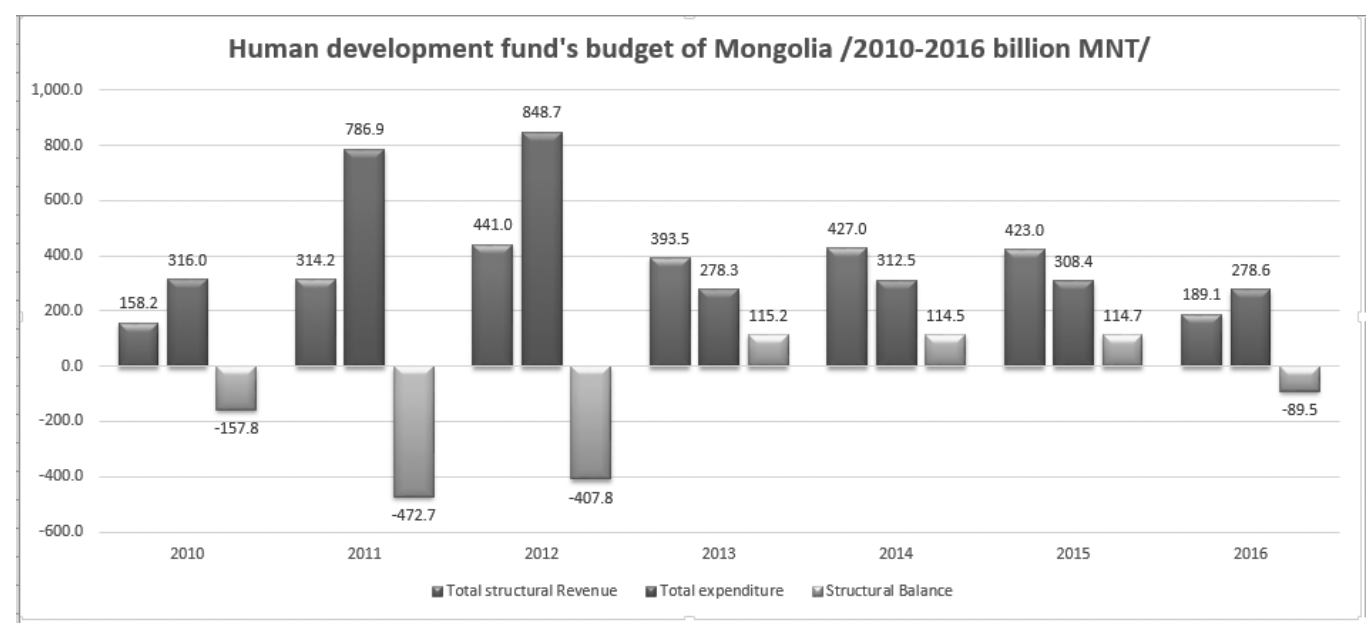

Graph 3. HDF's budget between 2010 and 2016. The blue bar shows revenue of HDF, and red bar indicates expenditure, and green bar illustrates the balance between revenue and expenditure (MOF, 2018).

started to implement Child Money Program (child benefit program) which providing monthly payments of MNT20,000 (about average of USD1123) to about one million children (aged 18 and below). Due to necessity of deciding the funding of this program the parliament made amendment on Law of HDF that the program of Child Money available fund from HDF. Since 2012, the HDF have received an extra annual obligation of about USD11 million for payment of Child Money Program which is approximately $1 \%$ of GDP. Overall, the HDF was active between 2010-2016, and during this time its expenditure was much higher compared to its revenue (graph 3) which entailed government to get a loan. The HDF budget table clearly shows that the total expenditure beyond its revenue, the total structure balance or over expenditure reached at MNT783,402 million (about USD318 million $^{24}$ ).
Why the HDF has established?

In 18 of November 2009, the Mongolian leading news portal news.mn reported that Law of HDF, Mongolia's Sovereign Wealth Fund was approved. Try to examine, why the parliament adopted this law in 2009 , not earlier or later. On the one hand, the Government of Mongolia has signed in agreement one of the biggest mining project Oyu Tolgoi with foreign investors in 2009. Oyu Tolgoi is one of the world's largest new copper-gold mines and is located in the South Gobi region of Mongolia, approximately $550 \mathrm{~km}$ south of the capital, Ulaanbaatar, and $80 \mathrm{~km}$ north of the Mongolia-China border. After decades of exploration and drilling, the first major discoveries at Oyu Tolgoi were made in 2001, leading to several years of further exploration which revealed the impressive scale of the deposit. While exploration continues, even

23 MNT20,000 was equal to USD14 in December 2012 and now equals to USD8 in August 2018. Thus, average USD11. 24 MNT783,402 million = USD318 million 


\section{All 580 Mines \& Deposits (Descending Order by Global In Situ Resource)}

\begin{tabular}{lllllll}
\multicolumn{2}{c}{ Deposit Name } & Tonnes $(\mathrm{mt})$ & Grade & Contained Oz & Location & Ownership \\
\hline 1 & Pebble Deposit & 10,776 & 0.31 & $107,269,278$ & USA, Alaska & Northern Dynasty \\
2 & Natalka & 1,693 & 1.68 & $91,179,118$ & Russia & Polyus Gold \\
3 & Grasberg & 4,765 & 0.56 & $85,800,000$ & Indonesia & Freeport Mcmoran \\
4 & South Deep & 415 & 6.10 & $81,330,718$ & Africa, South Africa & Goldfields \\
5 & Olimpiada & 748 & 3.22 & $77,435,009$ & Russia & Polyus Gold \\
6 & Lihir & 1,020 & 1.69 & $55,347,469$ & Papua New Guinea & Newcrest \\
7 & Mponeng & 111 & 14.24 & $50,832,453$ & Africa, South Africa & Anglogold Ashanti \\
8 & Muruntau & 625 & 2.49 & $50,000,000$ & Uzbekistan & Government of Uzbekistan \\
9 & KSM Deposit & 2,895 & 0.52 & $48,592,023$ & Canada, BC & Seabridge Gold \\
10 & Cadia Valley & 3,630 & 0.41 & $48,116,771$ & Australia & Newcrest \\
11 & Oyu Tolgoi & 3,755 & 0.38 & $46,070,529$ & Mongolia & Ivanhoe \\
12 & Donlin Creek & 634 & 2.20 & $44,854,369$ & USA, Alaska & Barrick/NovaGold \\
13 & Blyvoor & 548 & 2.43 & $42,912,145$ & Africa, South Africa & Village Main Reef \\
14 & Pueblo Viejo & 493 & 2.53 & $40,113,819$ & Dominican Republic & Barrick/Goldcorp \\
15 & Snowfield & 2,203 & 0.49 & $34,982,848$ & Canada, BC & Pretium Resources
\end{tabular}

Table 4. Global 2013 gold mine and deposit ranking (NRH, 2014)

with the reserves currently identified, Oyu Tolgoi is expected to operate for over 50 years (Tinto, n.d.). The Mining Journal of Mongolia (Mining Journal of Mongolia, 2013) reported that there are a lot of different statements regarding the amount of reserves of Oyu Tolgoi mining, but according to its feasibility study, approved in 2010, stated that its efficient or available extraction reserves deposit calculated as follows: 3 billion and 380 million tons of ore, 31.1 million tons of copper, 1328 tones of gold, 7601 tones of silver, and 81600 tones of molybdenum. According to Natural Resource Holdings' study (Global 2013 Gold Mine and Deposit Rankings, 2014) the Oyu Tolgoi mining ranked in $11^{\text {th }}$ place among 580 mines by its containing 46,070,529 oz gold (table 1).

In April 2007, a $\mathrm{MoU}$ was signed between IBRD, IFC, ADB, EBRD and the Ministry of Finance providing for broad support to the mining sector (WB, The Mongolia Minerals Sector - Key Issues, 2007). Furthermore, the signatories of the MoU stand ready to provide the necessary support to Government to retain the legal, financial and technical advice to conclude the negotiations of an investment agreement for Oyu Tolgoi. In other words, these International Organizations persist that there is an urgent need for Mongolia to conclude an investment agreement for Oyu Tolgoi, sending a strong signal to investors that the Government has realistic expectations, and is supportive of mineral development. A key element to attract and sustain investment and growth will be to re-establish and maintain the legislative and institutional stability, which was instrumental in spurring investment in Mongolia's mineral sector over the past few years (WB, The Mongolia Minerals Sector - Key Issues, 2007). As a result, The Oyu Tolgoi Investment Agreement and companion Shareholders' Agreement establish the framework for the development and operation of the Oyu Tolgoi coppergold mine. The Investment Agreement between the Government of Mongolia and Ivanhoe Mines Inc LLC, and Ivanhoe 


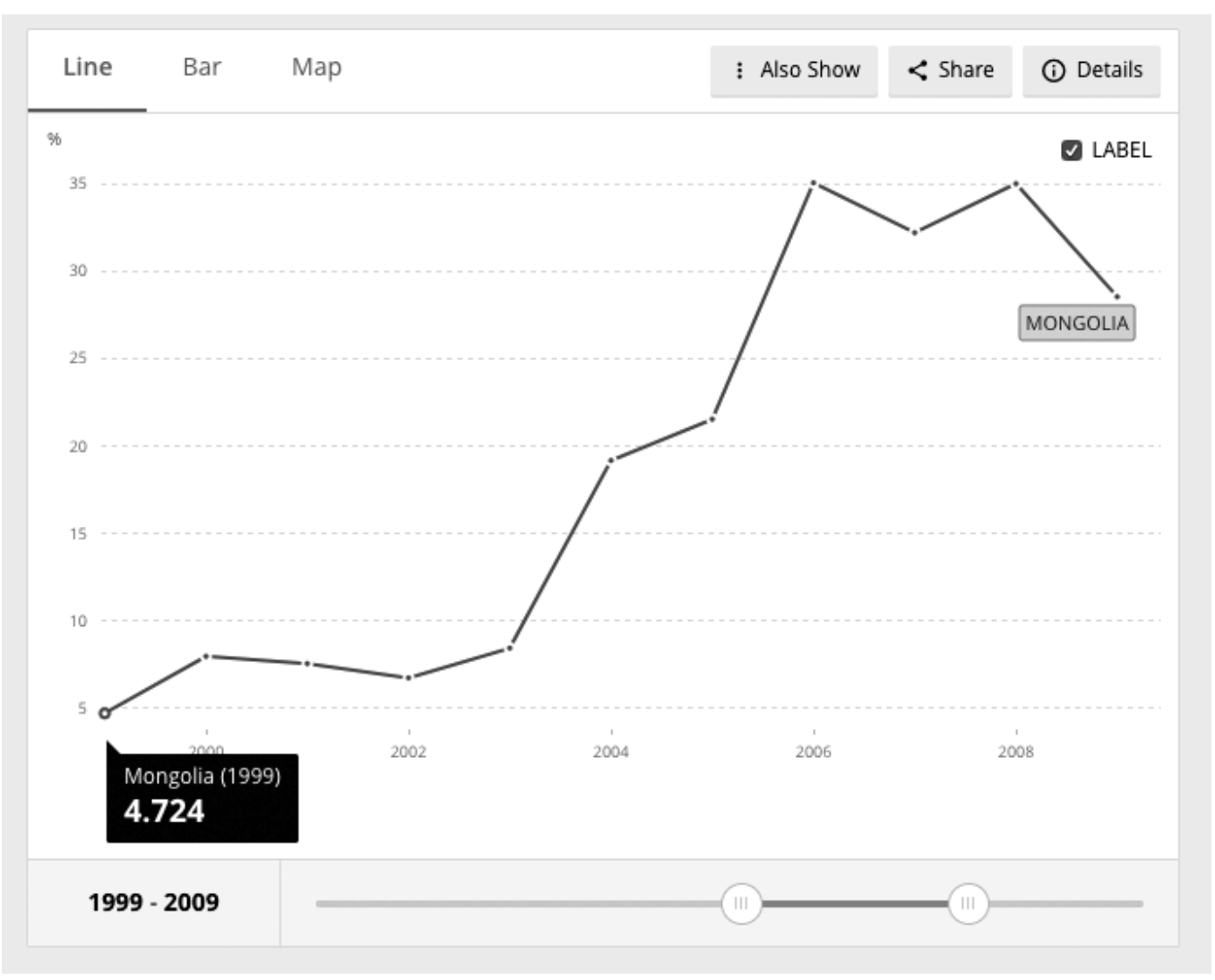

Graph 4. Total natural resources rents (\% of GDP) (WB, The World Bank Data, 2018).

Mines LLC, and Rio Tinto International Holdings Limited, signed in 2009, has an initial 30-year term with a 20-year extension (Hill, n.d.).

In addition, the revenue accumulation from mining sector in Mongolia has significantly increased since 2006. According to the World Bank statistics the total natural resources rents percentage of GDP increased by 7 times between 1999-2009 (graph 4). This fact shows that from 2006 to 2008 the rents from mineral has increased drastically.

On the other hand, the both leading parties of Mongolia, the Mongolian People's Party (MPP) and the Democratic Party (DP) promised that allocate the natural wealth to all citizens if they win in parliamentary election in 2008 . Parliamentary elections were held in Mongolia in $29^{\text {th }}$ June 2008. A total of 356 candidates ran for the 76 seats in parliament, and 45 seats were won by the ruling MPP, 28 seats by the main opposition party, the DP, 1 seat by Civil Will party, 1 seat by Green party, and 1 seat by independent candidate. According to law of government, the ruling party, leader of MPP was responsible to establish and appoint their cadre for the new government. First time ever, the prime minister Bayar Sanjaa established coalition government, constituted ministers from MPP and DP. Both parties' 
interests were coincided to establish SWF and allocate the natural resource wealth to their citizens. It is quite reasonable that windfall of mineral resource income led to establish SWF, but interesting that why government decided to allocate the money before accumulation asset in SWF? If see the overall balance of the HDF, early establishment of SWF, thereafter miscalculation and deficit of asset entailed to get a loan.

The first quarter of 2018, there are some interesting news broadcasted related to the Oyu Tolgoi agreement. The Financial Times (2018) reported that Mongolia's anti-corruption authority has arrested two former prime ministers who presided over key negotiations with Rio Tinto over its investments in the giant Oyu Tolgoi copper mine, upping the ante in a probe into the controversial project. Bayar Sanjaa, prime minister between 2007 and 2009, ambassador to the Great Britain since 2016, negotiated Rio Tinto's initial investment after it took over the mine from Canadian-listed developer Ivanhoe Mines. Saikhanbileg Chimed, who held office between 2014 and 2016, oversaw negotiations for the second, and more expensive, underground stage (Hornby, 2018). Prior a month, a Mongolian former finance minister, Bayartsogt Sangajav, has been arrested as part of an investigation into suspected abuse of power during investment talks for the Oyu Tolgoi copper mine in 2009, the anti-corruption agency said (Reuters, 2018). The Swiss Office of the Attorney General (OAG) is conducting a criminal investigation into a seized bank account that court documents indicated was used to transfer USD10 million to Bayartsogt in September 2008. Bayartsogt signed an agreement on behalf of Mongolia with Canada's Ivanhoe Mines in 2009 to develop the giant mine, granting a 66 percent controlling stake to the company (Reuters, 2018). All alleged politicians are realised from arrest because of health condition, and cases are under investigation. In some point, it is interesting that the date of adoption the agreement of the biggest mining company of Mongolia and law of the HDF is almost coinciding. It might be some politicians accelerated the time of establishment of the HDF to elude from public protest that signed in unfavourable agreement for Mongolian government. From giving statements, may conclude that the HDF established not accumulation of assets from natural resource, it was a vehicle and tool of political institution.

\section{The Fiscal Stability Fund}

In 2010, the Mongolian parliament approved the Fiscal Stability Law at a time of high commodity prices and strong economic growth. Between 2005 and 2008 the commodity price soared in world market, consequently the government revenue of Mongolia has increased dramatically because of expensed proceeds of copper and gold mining companies. The price of copper increased from USD3675 to USD6731 per ton, the price of gold increased by about 26 percent between 2005 and 2006 (G.Ragchaasuren, Impact of Fiscal Stability Law, 2014). This price soar did not last for long time, the price of copper fell from about USD7000 to USD5000 per ton between 2008 and 2009. The 
Coal price (USD per ton)

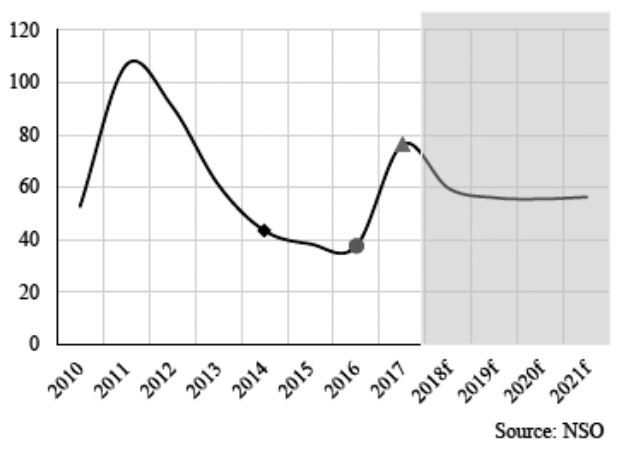

Copper price (USD per ton)

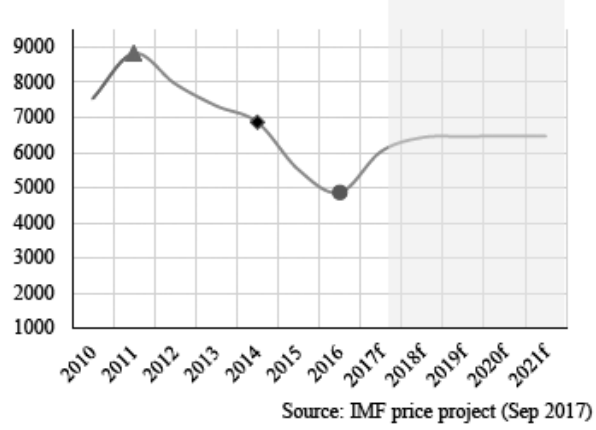

Graph 5. Coal and copper market price 2010-2017 (G.Ragchaasuren, et al., 2018, p. 4)

commodity price rocketed in 2011 and then constantly dropped till 2016 (graph $5)$.

The total expenditure has increased drastically when commodity price surged, in contrast drop of commodity price influenced slightly on national expenditure. For example, the expenditure has grown 6 times (by MNT4 billion) between 2006 and 2011

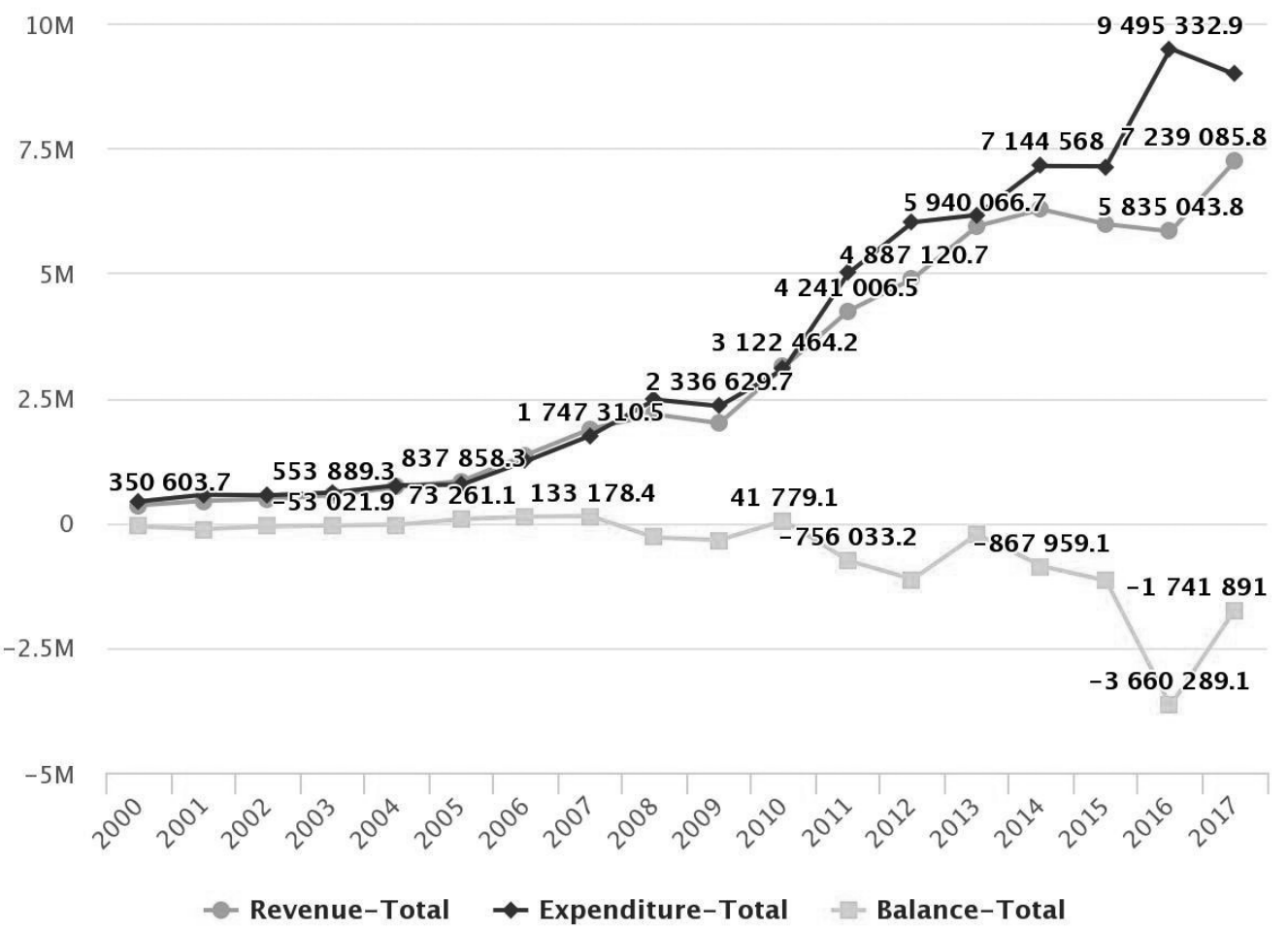

Graph 6. Mongolian general government balance by year. (MNT million) (MSIS, 2018) 


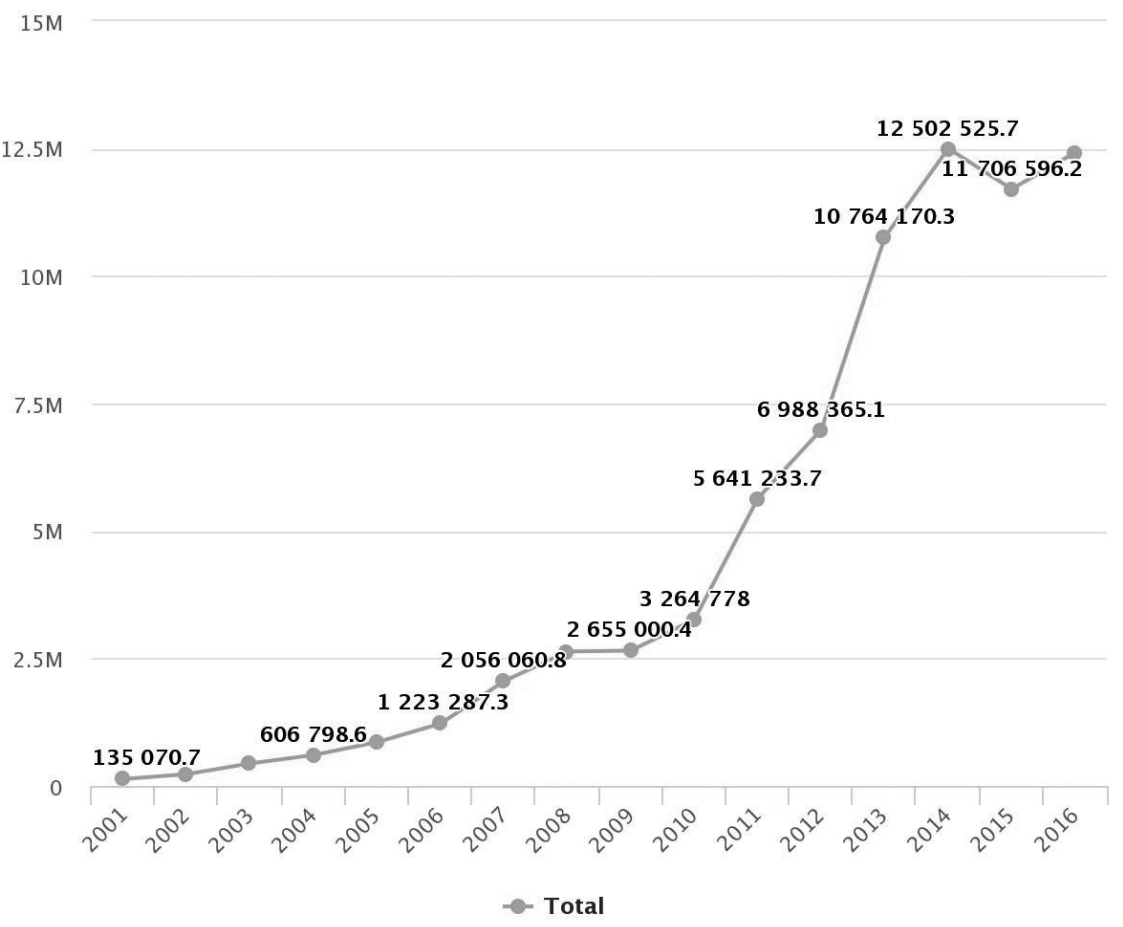

Graph 7. Outstanding loans. (MNT million) (MSIS, 2018)

during commodity price relatively high. Although, commodity price has fallen, the expenditure growth has been increasing with same rate between 2011 and 2016, by MNT4,6 billion (graph 6).

According to increase of government expenditure the total loan has increased. The loan between 2006 and 2010 had increased by MNT2 billion, then the loan has increased dramatically by MNT9.8 billion between 2010 and 2014. Increase of expenditure and loans emerged the government establish the FSF. But, it is difficult to stay the economy has stabilized by establishing FSF according to the government outstanding total loan data. The government expenditure persistently increased until involve the IMF's Extended Fund Facility (EFF) program in 2017.

According to the FSL, if the actual prices of the main mining products are higher than the equilibrated counterparts, the actual total revenue exceeds its predicted and hence the surplus must be saved in the FSF. The government aims to increase the FSF over time and maintain it to at least 5 percent of GDP thereafter. The fund will be used when the actual prices of the main mining products are realised to be less than the equilibrated prices to maintain the stability of fiscal positions. Any fund above 10 percent of GDP can be invested in specified economic activities such that it does not affect the stability of the economy, especially inflation (G.Ragchaasuren, Impact of Fiscal Stability Law, 2014, 


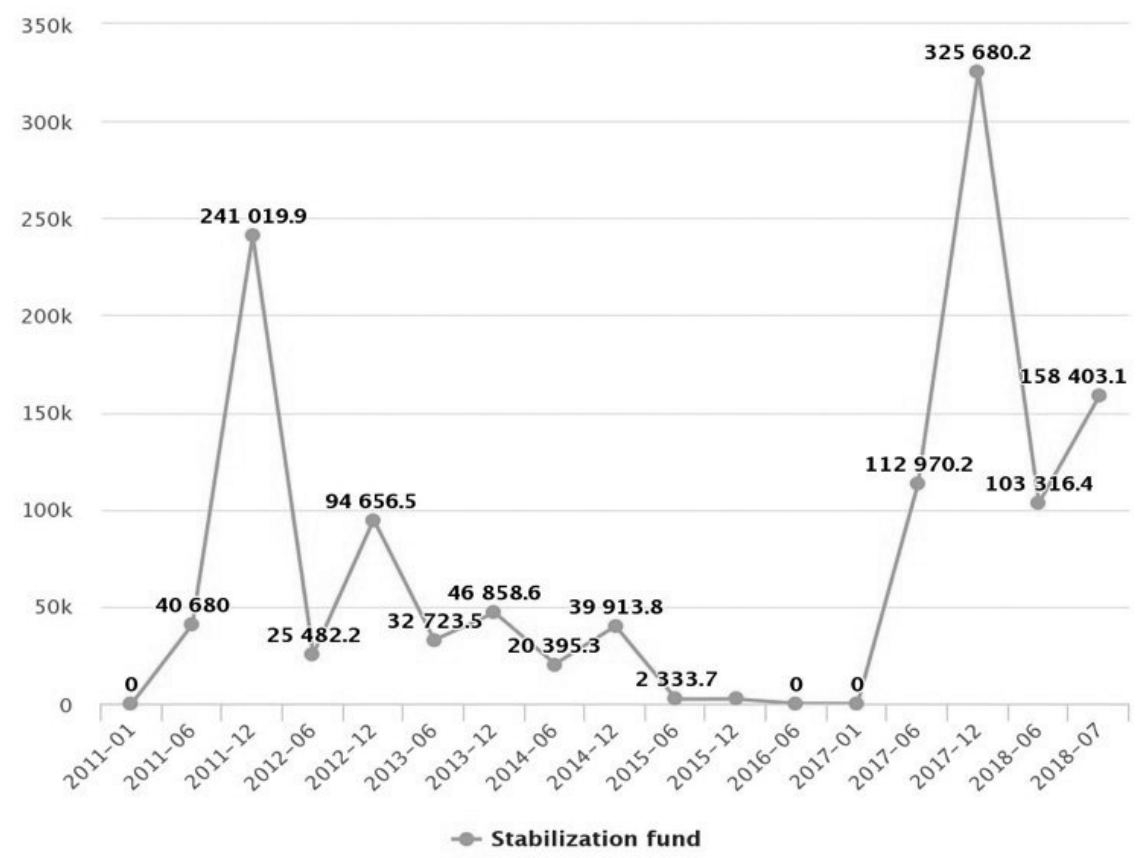

Graph 8. Stabilization fund revenue (MNT thousand) (MSIS, 2018)

p. 21). The FSF revenue is directly limited and external oversight is depended on commodity price, obscured. Therefore, it was difficult to particularly copper and coal. It can be examine to find the causal reason of seen that the FSF income drastically decrease of fund's resource. Overall, increased in 2011 and 2017 when coal the FSF fund deposit is significantly and copper price was higher compared dependent on mineral resource price to previous years (graph 5 and 8). The specifically copper, coal and gold. fund deposit of FSF has continuously According to data of fund's revenue, the decreased since it established, the fund of MNT241.0 billion in 2012 plunged down into MNT2.3 billion in 2015 (graph 8). According to $\mathrm{FSL}^{25}$ the fund's deposit must be not less than 5 percent of GDP, but this clause has abolished in 2017. If it was valid, the FSF committed to accumulate revenue of MNT5.58 billion (5 percent of GDP MNT27.8 billion), instead of MNT3.25 billion in 2017.

During the study the information about expenditure of FSF was very government tend to spend the deposit instead of increase, along parliament changing FSL's clauses when FSF unable to commit the regulation. The government was also consistently overoptimistic about its revenue projection (by about MNT1 trillion in each year) leading to higher budget deficit (Bauer, Galindev, Lkhagvajav, Mihalyi, \& Tuvaan, 2017, p. 27). The debt is expected to fall 50 percent of the GDP by implementing EFF program. However, 
Bauer et al., (2017) analysis shows that 15 percent permanent decrease in commodity price is likely to erase all the benefits of the IMF program indicating how vulnerable the economic situation is.

\section{Assessing the HDF and FSF through}

\section{Truman scoreboard}

There is no officially published papers assessed the Mongolian SWFs using Truman scoreboard and LMTI. Edwin Truman (A Blueprint for Sovereign Wealth Fund Best Practices, 2009) published a blueprint for SWF best practices based on a scoreboard for the current practices of $44 \mathrm{SWFs}$, excluding Mongolian SWFs, maybe because it does not have a good practice, or might be insufficient information to evaluate SWFs. Thus, it motivates to examine the HDF and FSF of Mongolia using Truman scoreboard and evaluate the result in which level the SWF are in. The scoreboard has updated its questioning elements since its first assessment. The initial scoreboard (Truman E. M., A Scoreboard for Sovereign Wealth Funds, 2007) contained 25 elements, the last assessment (Truman E. M., Progress on SWF Transparency and Accountability: An Updated SWF Scoreboard , 2013) used 33 elements which constructed as questions and are grouped in four categories: the first category is structure of the fund, including its objectives, fiscal treatment, and whether it is separate from the country's international reserves; the second category is governance of the fund, including the roles of the government and the managers, and whether the fund follows guidelines for corporate responsibility and ethical investment behaviour; the third category is accountability and transparency of the fund in its investment strategy, investment activities, reporting and audits; and the last category is a behaviour of the fund in managing its portfolio and in the use of leverage and derivatives.

The structure category shows the ability of SWF to treat the maintaining macroeconomic stability of a country, the compliance of regulation of fund, and whether SWF has clearly stated its investment strategy. The governance category more focused on more managing and operational issues such as respective roles of government and managers, procedure of making decision, and ethical guidelines. The transparency and accountability illustrate the openness of SWF operation and structure to public, which is important indicator of democracy. In other words, Mongolia is a democratic country, therefore this category may exhibit its level of democracy.

Below table shows the result of Mongolian SWFs' transparency and accountability by exploiting the method of Truman scoreboard and LMTI. 


\begin{tabular}{|c|c|c|c|c|c|}
\hline \multirow{2}{*}{ No. } & \multirow{2}{*}{ Questions } & \multicolumn{2}{|c|}{ Scores } & \multicolumn{2}{|c|}{ Answers } \\
\hline & & HDF & FSF & HDF & FSF \\
\hline \multicolumn{6}{|c|}{ One. Structure } \\
\hline 1.1 & $\begin{array}{l}\text { Is the SWF's objective } \\
\text { clearly stated? (p) }\end{array}$ & 100 & 100 & $\begin{array}{l}\text { According the article } 1.1 \\
\text { of HDFL create a savings } \\
\text { from commodity revenue, } \\
\text { and allocate to citizens } \\
\text { equally }\end{array}$ & $\begin{array}{l}\text { According the article } \\
16.1 \text { of FSL the } \\
\text { purpose of FSF is to } \\
\text { maintain the fiscal } \\
\text { stability of national } \\
\text { budget in short and } \\
\text { long term (three years } \\
\text { and more). }\end{array}$ \\
\hline 1.2 & $\begin{array}{l}\text { Is the source of the } \\
\text { SWF's funding clearly } \\
\text { specified? }\end{array}$ & 100 & 100 & $\begin{array}{l}\text { According the article } 3.2 \\
\text { of HDFL stated clearly } \\
\text { that HDF's funding source } \\
\text { are dividend and royalty, } \\
\text { and other profit from } \\
\text { loans. }\end{array}$ & $\begin{array}{l}\text { According article } 16.2 \\
\text { of FSL, the FSF will } \\
\text { fund from structural } \\
\text { balance of budget, } \\
\text { unspecified balance of } \\
\text { reserve and risk fund, } \\
\text { other incomes allocated } \\
\text { from parliament }\end{array}$ \\
\hline 1.3 & $\begin{array}{l}\text { Is nature of the } \\
\text { subsequent use of the } \\
\text { principal and earnings } \\
\text { in the fund clearly } \\
\text { stated? (p) }\end{array}$ & 100 & 100 & $\begin{array}{l}\text { According to the article } \\
4.1 \text { of HDFL, clearly } \\
\text { stated regulation of the } \\
\text { earnings. }\end{array}$ & $\begin{array}{l}\text { According to the article } \\
6 \text { and } 7 \text { of FSL, clearly } \\
\text { stated principal and } \\
\text { earnings in the fund. }\end{array}$ \\
\hline 1.4 & $\begin{array}{l}\text { Are these elements } \\
\text { of fiscal treatment } \\
\text { integrated with the } \\
\text { budget? }(p)\end{array}$ & 100 & 100 & $\begin{array}{l}\text { According to the article } \\
18.1 \text { of HDFL, the } \\
\text { government prepare the } \\
\text { funds budget and apply } \\
\text { to the national budget } \\
\text { through parliament }\end{array}$ & $\begin{array}{l}\text { According to the } \\
\text { annual Budget Law } \\
\text { the fiscal treatment } \\
\text { integrated with the } \\
\text { budget. }\end{array}$ \\
\hline \multicolumn{6}{|c|}{1.2 Fiscal treatment } \\
\hline 1.2 .1 & $\begin{array}{|lr|}\text { Are the } & \text { guidelines } \\
\text { for fiscal } & \text { treatment } \\
\text { generally } & \text { followed } \\
\text { without } & \text { frequent } \\
\text { adjustment? }(\mathrm{p})\end{array}$ & 0 & 0 & $\begin{array}{l}\text { There is no information } \\
\text { publicly disclosed }\end{array}$ & $\begin{array}{l}\text { There is no information } \\
\text { publicly disclosed }\end{array}$ \\
\hline 1.2 .2 & 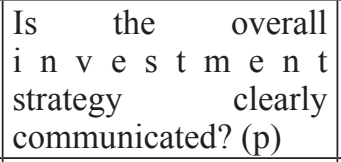 & 50 & 100 & $\begin{array}{l}\text { The article } 6.1 \text { of the } \\
\text { HDFL stated generally } \\
\text { about investment strategy. }\end{array}$ & $\begin{array}{l}\text { The article } 17 \text { of the } \\
\text { BFL clearly stated } \\
\text { about investment } \\
\text { strategy. }\end{array}$ \\
\hline 1.2 .3 & $\begin{array}{l}\text { Is the procedure for } \\
\text { changing the structure } \\
\text { clear? (p) }\end{array}$ & 0 & 0 & $\begin{array}{l}\text { No information about } \\
\text { changing structure }\end{array}$ & $\begin{array}{l}\text { No information about } \\
\text { changing structure }\end{array}$ \\
\hline 1.2 .4 & $\begin{array}{l}\text { Is the SWF separate } \\
\text { from the country's } \\
\text { international reserves? }\end{array}$ & 100 & 0 & $\begin{array}{l}\text { According to the article } \\
7.1 \text { of the HDFL, fund } \\
\text { may establish independent } \\
\text { risk reserve in central } \\
\text { bank. }\end{array}$ & $\begin{array}{l}\text { No distinct information } \\
\text { about reserve }\end{array}$ \\
\hline
\end{tabular}




\begin{tabular}{|c|c|c|c|c|c|}
\hline \multicolumn{6}{|c|}{ Two. Governance } \\
\hline 2.1 & $\begin{array}{l}\text { Is the role of the } \\
\text { government in setting } \\
\text { the investment } \\
\text { strategy of the SWF } \\
\text { clearly established? } \\
\text { (p) }\end{array}$ & 0 & 50 & $\begin{array}{l}\text { There is no clearly } \\
\text { established investing } \\
\text { strategy of the SWF. }\end{array}$ & $\begin{array}{l}\text { According to the } \\
\text { article } 17.1 \text { of the FSL, } \\
\text { the president of Central } \\
\text { Bank responsible } \\
\text { setting the strategy } \\
\text { of investment, but no } \\
\text { clear regulation. }\end{array}$ \\
\hline 2.2 & $\begin{array}{l}\text { Is the role of the } \\
\text { governing body of the } \\
\text { SWF clearly } \\
\text { established? (p) }\end{array}$ & 100 & 100 & $\begin{array}{l}\text { The section three of the } \\
\text { HDFL stated clearly about } \\
\text { governing body of the } \\
\text { SWF. }\end{array}$ & $\begin{array}{l}\text { In the section three of } \\
\text { the FSL clearly stated } \\
\text { role of parliament, } \\
\text { government and MOF. }\end{array}$ \\
\hline 2.3 & $\begin{array}{l}\text { Is the role of the } \\
\text { managers in executing } \\
\text { the investment } \\
\text { strategy clearly } \\
\text { established? (p) }\end{array}$ & 50 & 100 & $\begin{array}{l}\text { In the article } 21 \text { of the } \\
\text { HDFL stated general } \\
\text { managing role of MOF. }\end{array}$ & $\begin{array}{l}\text { The article } 17 \text { of FSL } \\
\text { clearly stated about } \\
\text { managers role in } \\
\text { investment }\end{array}$ \\
\hline 2.4 & $\begin{array}{l}\text { Are decisions on } \\
\text { specific investments } \\
\text { made by the } \\
\text { managers? }(p)\end{array}$ & 0 & 0 & $\begin{array}{l}\text { No information disclosed } \\
\text { publicly }\end{array}$ & $\begin{array}{l}\text { No } \quad \text { information } \\
\text { disclosed publicly }\end{array}$ \\
\hline 2.5 & $\begin{array}{l}\text { Does the SWF have } \\
\text { internal ethical } \\
\text { standards for its } \\
\text { management and } \\
\text { staff? }\end{array}$ & 0 & 0 & No regulation & No regulation \\
\hline 2.6 & $\begin{array}{l}\text { Does the SWF } \\
\text { have in place, and } \\
\text { make publicly } \\
\text { available, guidelines } \\
\text { for rorporate } \\
\text { responsibility that it } \\
\text { follows? (p) }\end{array}$ & 0 & 0 & No information & No information \\
\hline 2.7 & $\begin{array}{l}\text { Does the SWF have } \\
\text { ethical investment } \\
\text { guidelines that it } \\
\text { follows? (p) }\end{array}$ & 0 & 0 & $\begin{array}{l}\text { No information about } \\
\text { ethical guidelines }\end{array}$ & $\begin{array}{l}\text { No information about } \\
\text { ethical guidelines }\end{array}$ \\
\hline \multicolumn{6}{|c|}{ Three. Transparency and accountability } \\
\hline \multicolumn{6}{|c|}{ 3.1 Investments strategy implementation } \\
\hline 3.1 .1 & \begin{tabular}{|l} 
Do regular reports on \\
investments by the \\
SWF include \\
information on \\
the categories of \\
investments? (p) \\
\end{tabular} & 50 & 50 & $\begin{array}{l}\text { There are some reports } \\
\text { published on MOF and } \\
\text { www.iltod.mn websites, } \\
\text { but not regularly }\end{array}$ & $\begin{array}{l}\text { There are some } \\
\text { reports published on } \\
\text { MOF and www.iltod. } \\
\text { mn websites, but not } \\
\text { regularly }\end{array}$ \\
\hline 3.1 .2 & $\begin{array}{l}\text { Does the strategy use } \\
\text { benchmarks? (p) }\end{array}$ & 0 & 0 & $\begin{array}{l}\text { No information for public } \\
\text { about benchmarks }\end{array}$ & $\begin{array}{l}\text { No information about } \\
\text { for public benchmarks }\end{array}$ \\
\hline 3.1 .3 & $\begin{array}{l}\text { Does the strategy use } \\
\text { credit ratings? (p) }\end{array}$ & 0 & 0 & $\begin{array}{l}\text { No information for public } \\
\text { about strategy use of } \\
\text { credits }\end{array}$ & $\begin{array}{l}\text { No information for } \\
\text { public about strategy } \\
\text { use of credits }\end{array}$ \\
\hline
\end{tabular}




\begin{tabular}{|c|c|c|c|c|c|}
\hline 3.1 .4 & $\begin{array}{l}\text { Are the holders of } \\
\text { investment mandates } \\
\text { identified? }(\mathrm{p})\end{array}$ & 0 & 0 & No information for public & $\begin{array}{l}\text { No information for } \\
\text { public }\end{array}$ \\
\hline \multicolumn{6}{|c|}{3.2 Investment activities } \\
\hline 3.2 .1 & $\begin{array}{l}\text { Do regular reports on } \\
\text { the investments by the } \\
\text { SWF include the size } \\
\text { of the fund? (p) }\end{array}$ & 0 & 0 & $\begin{array}{l}\text { There are no reports } \\
\text { publicly published }\end{array}$ & $\begin{array}{l}\text { There are no reports } \\
\text { publicly published }\end{array}$ \\
\hline 3.2 .2 & $\begin{array}{l}\text { Do regular reports } \\
\text { on the investments } \\
\text { by the SWF include } \\
\text { information on the } \\
\text { returns? (p) }\end{array}$ & 0 & 0 & $\begin{array}{l}\text { The are no reports publicly } \\
\text { published }\end{array}$ & $\begin{array}{l}\text { There are no reports } \\
\text { publicly published }\end{array}$ \\
\hline 3.2 .3 & $\begin{array}{l}\text { Do regular reports on } \\
\text { the investments by the } \\
\text { SWF include } \\
\text { information on the } \\
\text { geographic location of } \\
\text { investments? (p) }\end{array}$ & 0 & 0 & $\begin{array}{l}\text { The are no reports publicly } \\
\text { published }\end{array}$ & $\begin{array}{l}\text { The are no reports } \\
\text { publicly published }\end{array}$ \\
\hline 3.2 .4 & $\begin{array}{l}\text { Do regular reports on } \\
\text { the investments by the } \\
\text { SWF include } \\
\text { information on the } \\
\text { specific investments? } \\
\text { (p) }\end{array}$ & 0 & 0 & $\begin{array}{l}\text { The are no reports publicly } \\
\text { published }\end{array}$ & $\begin{array}{l}\text { The are no reports } \\
\text { publicly published }\end{array}$ \\
\hline 3.2 .5 & $\begin{array}{l}\text { Do regular reports on } \\
\text { the investments by the } \\
\text { SWF include } \\
\text { information on the } \\
\text { currency composition } \\
\text { of investments? (p) }\end{array}$ & 0 & 0 & $\begin{array}{l}\text { The are no reports publicly } \\
\text { published }\end{array}$ & $\begin{array}{l}\text { The are no reports } \\
\text { publicly published }\end{array}$ \\
\hline \multicolumn{6}{|c|}{3.3 Reports } \\
\hline 3.3 .1 & $\begin{array}{l}\text { Does the SWF provide } \\
\text { at least an annual } \\
\text { report on its } \\
\text { activities and results? } \\
\text { (p) }\end{array}$ & 100 & 0 & $\begin{array}{l}\text { According to the article } \\
12.1 \text { of HDFL, the fund } \\
\text { should publish report } \\
\text { twice a year }\end{array}$ & $\begin{array}{l}\text { There is no regulation } \\
\text { about periodic reports. }\end{array}$ \\
\hline 3.3 .2 & $\begin{array}{l}\text { Does the SWF provide } \\
\text { quarterly reports? (p) }\end{array}$ & 50 & 0 & $\begin{array}{l}\text { According to the article } \\
12.1 \text { of HDFL, the fund } \\
\text { should publish report } \\
\text { twice a year }\end{array}$ & $\begin{array}{l}\text { There is no regulation } \\
\text { about periodic reports. }\end{array}$ \\
\hline \multicolumn{6}{|c|}{3.3 Audits } \\
\hline 3.3 .1 & $\begin{array}{l}\text { Is the SWF subject to } \\
\text { a regular annual audit? } \\
\text { (p) }\end{array}$ & 100 & 0 & $\begin{array}{l}\text { According to the article } \\
22 \text { of HDFL, the external } \\
\text { auditing required at least } \\
\text { once a year. }\end{array}$ & $\begin{array}{l}\text { There is no regulation } \\
\text { about regular auditing. }\end{array}$ \\
\hline
\end{tabular}




\begin{tabular}{|c|c|c|c|c|c|}
\hline 3.3 .2 & $\begin{array}{l}\text { Does the SWF publish } \\
\text { promptly the audits of } \\
\text { its } \\
\text { operations and } \\
\text { accounts? (p) }\end{array}$ & 50 & 0 & $\begin{array}{l}\text { There are two audit reports } \\
\text { publicly disclosed }{ }^{26}\end{array}$ & $\begin{array}{l}\text { There is no annual } \\
\text { report of FSF was } \\
\text { found by searching } \\
\text { following websites of } \\
\text { MOF, MMHI, NAO }\end{array}$ \\
\hline 3.3 .3 & $\begin{array}{l}\text { Are the audits } \\
\text { independent? }(\mathrm{p})\end{array}$ & 100 & 100 & $\begin{array}{l}\text { National Audit Authority } \\
\text { is an independent } \\
\text { organization. }\end{array}$ & $\begin{array}{l}\text { National } \\
\text { Authority is audit } \\
\mathrm{i} \mathrm{nd} \text { e p e } \mathrm{n} d \text { e } \mathrm{n} \mathrm{t} \\
\text { organization. }\end{array}$ \\
\hline \multicolumn{6}{|c|}{ Four. Behaviour } \\
\hline 4.1 & $\begin{array}{l}\text { Does the SWF have } \\
\text { an operational risk } \\
\text { management policy? }\end{array}$ & 100 & 0 & $\begin{array}{l}\text { According to the article } \\
14.1 \text { of HDFL, the MOF } \\
\text { responsible to determine } \\
\text { and manage the risk. }\end{array}$ & $\begin{array}{l}\text { No regulation about } \\
\text { operational risk } \\
\text { management policy. }\end{array}$ \\
\hline 4.2 & $\begin{array}{l}\text { Does the SWF have } \\
\text { a policy on the use of } \\
\text { leverage? }(p)\end{array}$ & 0 & 100 & $\begin{array}{l}\text { No policy using of } \\
\text { leverage }\end{array}$ & $\begin{array}{l}\text { According to article } \\
\begin{array}{l}17.3 .6 \text { of } \\
\text { prohibited use } \\
\text { leverage. }\end{array} \\
\text { lever }\end{array}$ \\
\hline 4.3 & $\begin{array}{l}\text { Does the SWF have } \\
\text { a policy on the use of } \\
\text { derivatives? (p) }\end{array}$ & 100 & 100 & $\begin{array}{l}\text { According to the article } \\
5.1 \text { of HDFL, in order to } \\
\text { increase the fund revenue } \\
\text { may invest domestic or } \\
\text { foreign securities, bond } \\
\text { and savings. }\end{array}$ & $\begin{array}{l}\text { The article } 16 \text { and } 17 \\
\text { explicit the policy on } \\
\text { the use of derivatives. }\end{array}$ \\
\hline 4.4 & $\begin{array}{l}\text { Does the SWF have } \\
\text { a guideline on the } \\
\text { nature and speed } \\
\text { of adjustment in its } \\
\text { portfolio? (p) }\end{array}$ & 0 & 0 & $\begin{array}{l}\text { No guideline on the nature } \\
\text { and speed of adjustment of } \\
\text { portfolio. }\end{array}$ & $\begin{array}{l}\text { No guideline on the } \\
\text { nature and speed } \\
\text { of adjustment of } \\
\text { portfolio. }\end{array}$ \\
\hline \multicolumn{2}{|c|}{ Overall average score } & 41 & 33 & & \\
\hline
\end{tabular}

Table 1. Truman Scoreboard assessment questions (Truman E. M., Progress on SWF Transparency and Accountability: An Updated SWF Scoreboard, 2013)

The average score of the HDF and FSF equal to 37 which illustrate a weak performance and by SWF scoreboard (appendix 4) these funds will rank between Brazilian Sovereign Fund (score is 30) and Iranian National Development Fund (score is 41). The statistic of the HDF (graph 3) shows that fund's expenditure surpassed the revenue, thus the management was inefficient. Similarly, the FSF has weak management because it has not been accumulating proposed revenue from government. The evaluation by Truman scoreboard score also shows a weak performance of SWF. ${ }^{26}$

26 National Audit Authority's report in 2017. https://www.audit.mn/wp-content/uploads/2017/05/hunii-hogjil-san.pdf National Audit Authority's report regarding the HDF's revenue and expenditure in 2014. http://www.audit.gov.mn/ files/report/compliance/hugjil-san.pdf 
Assessing through LMTI

\begin{tabular}{|l|l|c|c|}
\hline No. & Enquiries & \multicolumn{2}{|c|}{ Scores } \\
\cline { 2 - 3 } & & HDF & FSF \\
\hline 1 & $\begin{array}{l}\text { Fund provides history including reason for creation, origins of wealth, and } \\
\text { government ownership structure }\end{array}$ & 1 \\
\hline 2 & Fund provides up-to-date independently audited annual reports & 1 & 1 \\
\hline 3 & $\begin{array}{l}\text { Fund provides ownership percentage of company holdings, and geographic } \\
\text { locations of holdings }\end{array}$ & 0 & 0 \\
\hline 4 & $\begin{array}{l}\text { Fund provides total portfolio market value, returns, and management } \\
\text { compensation }\end{array}$ & 0 & 0 \\
\hline 5 & $\begin{array}{l}\text { Fund provides guidelines in reference to ethical standards, investment } \\
\text { policies, and enforcer of guidelines }\end{array}$ & 0 & 0 \\
\hline 6 & Fund provides clear strategies and objectives & 1 & 1 \\
\hline 7 & If applicable, the fund clearly identifies subsidiaries and contact information & 0 & 0 \\
\hline 8 & If applicable, the fund identifies external managers & 0 & 1 \\
\hline 9 & Fund manages its own web site & 0 & 0 \\
\hline 10 & $\begin{array}{l}\text { Fund provides main office location address and contact information such } \\
\text { as telephone and fax }\end{array}$ & 0 & 0 \\
\hline Overall score & 3 & 4 \\
\hline
\end{tabular}

Table 3. Linaburg-Maduell Transparency Index (SWFI, SWF Institute-LMTI, 2018)

The LMTI illustrates very poor result regarding the HDF and FSF's transparency and accountability. It also confirms that these funds have an inefficient management.

Assessment through resource governance index

The index has formulated using a framework of 149 critical questions to define the resource governance as the rules, disclosures, oversight procedures and measure environment allowance whether citizens can hold their government to account for managing their extractive resource wealth. The RGI has 51 questions devoted to measuring presence or rules - laws regulations or government policy documents; 67 questions related to disclosures - data (e.g. beneficial ownership), processes (e.g. what happens before and after a licensing round), and availability of analytical reports published by government agencies and organizations; 7 questions related to oversight - audits and appointment of independent oversight bodies. Also, RGI measures the quality of the enabling environment - wide range of processes in the government, parliament, media, and civil society that enables or disable the effectiveness 
of resource policies and governance for resource governance. All answers substitute of 100 points, which indicate country with more than 75 points has a good resource governance - a country has established laws and practices that are likely to result in extractive resource wealth benefiting citizens, although there may be some cost to society; $60-74$ points is satisfactory resource governancecountries has some strong governance procedures and practices, but some areas need improvement; $45-59$ points is weak resource governance - country has a mix of strong and problematic areas of governance; 30-44 points is poor country has established some minimal procedures and practices to govern resources, but most elements necessary to ensure the society benefits are missing; less 30 points failing - country has almost no governance framework to ensure resource extraction benefits society (NRGI, 2017).

\begin{tabular}{|c|c|c|c|}
\hline No. & Questions & Scores & Answers (HDF) \\
\hline 2.3 & $\begin{array}{l}\text { SWF existence } \\
\text { Does the country have a natural resource } \\
\text { fund which is funded by extractive } \\
\text { resource revenues? }\end{array}$ & & $\begin{array}{l}\text { There are two active SWFs: FSF } \\
\text { and FHF (replaced the HDF) }\end{array}$ \\
\hline 2.3.1 & \multicolumn{3}{|l|}{ SWF deposit and withdrawal rules } \\
\hline a) & $\begin{array}{l}\text { SWF withdrawal rule } \\
\text { Are there numeric rules governing size of } \\
\text { withdrawals from the SWF? }\end{array}$ & 100 & $\begin{array}{l}\text { According to the article } 15.1 \text { of } \\
\text { HDFL, the Parliament approve } \\
\text { the amount in accordance with } \\
\text { Government suggestion. }\end{array}$ \\
\hline b) & $\begin{array}{l}\text { SWF national budget review } \\
\text { requirement } \\
\text { Do rules require that withdrawals and } \\
\text { spending from the SWF pass through the } \\
\text { national budget? }\end{array}$ & 100 & $\begin{array}{l}\text { According to the article } 17.5 \text { of } \\
\text { HDFL, the government approve the } \\
\text { withdrawal procedure }\end{array}$ \\
\hline c) & $\begin{array}{l}\text { SWF deposit rule } \\
\text { Are the numeric rules governing the size } \\
\text { of deposits into the SWF }\end{array}$ & 100 & $\begin{array}{l}\text { Annually adopted budget law of the } \\
\text { HDF by parliament. }\end{array}$ \\
\hline 2.3.2 & \multicolumn{3}{|l|}{ SWF deposit and withdrawal practice } \\
\hline a) & $\begin{array}{l}\text { SWF size of fund disclosure } \\
\text { Does the SWF's most recent publicly } \\
\text { available financial report specify the size } \\
\text { of the fund? }\end{array}$ & 50 & $\begin{array}{l}\text { The NSOM published the total } \\
\text { revenue and expenditure, but there } \\
\text { is no disclosed financial report. }\end{array}$ \\
\hline b) & $\begin{array}{l}\text { SWF deposit and withdrawal amounts } \\
\text { disclosure } \\
\text { Does the SWF's most recent publicly } \\
\text { available annual financial report disclose } \\
\text { deposit and withdrawal amounts? }\end{array}$ & 50 & $\begin{array}{l}\text { The MOF disclosed overall } \\
\text { structural balance of the HDF } \\
\text { from } 2010 \text { to } 2016 \text {. But no further } \\
\text { detailed information. }\end{array}$ \\
\hline
\end{tabular}




\begin{tabular}{|c|c|c|c|}
\hline c) & $\begin{array}{l}\text { SWF withdrawal rule adherence } \\
\text { From } 2015 \text { onwards, has the government } \\
\text { adhered to the numeric rules governing } \\
\text { the size of withdrawals from SWFs? }\end{array}$ & 50 & $\begin{array}{l}\text { The government promised to } \\
\text { allocate the revenue for citizens } \\
\text { which is not accumulated. This } \\
\text { promise entailed to break the } \\
\text { withdrawal rule adherence. Adhered } \\
\text { the rules but not completely. }\end{array}$ \\
\hline d) & $\begin{array}{l}\text { SWF deposit rule adherence } \\
\text { From } 2015 \text { onwards, has the government } \\
\text { adhered to the numeric rules governing } \\
\text { the size of deposits into the SWF? }\end{array}$ & 75 & $\begin{array}{l}\text { According to HDF annual budget } \\
\text { law government adhered the deposit } \\
\text { rule. The numeric size was volatile } \\
\text { because of commodity price change. }\end{array}$ \\
\hline 2.3.3 & \multicolumn{3}{|l|}{ SWF Investment Rules } \\
\hline a) & $\begin{array}{l}\text { SWF domestic investment } \\
\text { Is the SWF prohibited from investing } \\
\text { in domestic assets without budgetary } \\
\text { approval? }\end{array}$ & 25 & $\begin{array}{l}\text { According to the article } 5.1 \text { of } \\
\text { HDFL, in order to increase the fund } \\
\text { revenue may invest domestic or } \\
\text { foreign securities, bond and savings. } \\
\text { No specific regulation. }\end{array}$ \\
\hline b) & $\begin{array}{l}\text { SWF asset class rule } \\
\text { Is the SWF prohibited from investing in } \\
\text { certain asset classes or investment types? }\end{array}$ & 100 & $\begin{array}{l}\text { According to the article } 24.1 \text { of } \\
\text { HDFL, prohibited to spend the fund } \\
\text { any other purposes beyond the law. }\end{array}$ \\
\hline 2.3.4 & \multicolumn{3}{|l|}{ SWF Investment Practice } \\
\hline a) & $\begin{array}{l}\text { SWF rate of return disclosure } \\
\text { Does the SWF's most recent publicly } \\
\text { available annual financial report specify } \\
\text { the rate of return made on its investments? }\end{array}$ & 0 & $\begin{array}{l}\text { No publicly disclosed annual } \\
\text { financial report. No investments. }\end{array}$ \\
\hline b) & $\begin{array}{l}\text { SWF assets held disclosure } \\
\text { Does the SWF's most recent publicly } \\
\text { available annual financial report include } \\
\text { a list of assets held? }\end{array}$ & 0 & $\begin{array}{l}\text { No publicly disclosed annual } \\
\text { financial report. }\end{array}$ \\
\hline c) & $\begin{array}{l}\text { SWF asset class disclosure } \\
\text { Does the SWF's most recent publicly } \\
\text { available annual financial report specify } \\
\text { the fund's allocation by asset class? }\end{array}$ & 0 & $\begin{array}{l}\text { No publicly disclosed annual } \\
\text { financial report. }\end{array}$ \\
\hline d) & $\begin{array}{l}\text { SWF national budget review practice } \\
\text { From } 2015 \text { onward, have withdrawal and } \\
\text { spending from the SWF actually passed } \\
\text { through the national budget? }\end{array}$ & 100 & $\begin{array}{l}\text { The withdrawal and spending from } \\
\text { HDF has passed through HDF } \\
\text { budget law by parliament }\end{array}$ \\
\hline e) & $\begin{array}{l}\text { SWF asset class rule adherence } \\
\text { From } 2015 \text { onwards, has the SWF adhered } \\
\text { to rule limiting asset class or investment } \\
\text { types? }\end{array}$ & 25 & $\begin{array}{l}\text { According to the article } 5.1 \text { of } \\
\text { HDFL, in order to increase the } \\
\text { fund revenue may invest domestic } \\
\text { or foreign securities, bond and } \\
\text { savings. Prohibited other investment } \\
\text { according to the article } 24.1 \text { of } \\
\text { HDFL. }\end{array}$ \\
\hline
\end{tabular}




\begin{tabular}{|c|c|c|c|}
\hline 2.3.5 & \multicolumn{3}{|l|}{ SWF Financial Reporting Rules } \\
\hline a) & $\begin{array}{l}\text { SWF annual financial reporting } \\
\text { requirement } \\
\text { Is the SWF required to produce annual } \\
\text { financial reports? }\end{array}$ & 75 & $\begin{array}{l}\text { According to the article } 20.1 \text { of } \\
\text { HDFL, the MOF responsible to } \\
\text { produce the financial reports. } \\
\text { According to the law no specific } \\
\text { regulation about time routine. }\end{array}$ \\
\hline b) & $\begin{array}{l}\text { SWF financial report disclosure rule } \\
\text { Is the SWF required to publicly disclose } \\
\text { these annual financial reports? }\end{array}$ & 100 & $\begin{array}{l}\text { According to the article } 23 \text { of } \\
\text { HDFL, the annual financial reports } \\
\text { required to disclose through public } \\
\text { media. }\end{array}$ \\
\hline c) & $\begin{array}{l}\text { SWF financial audit requirement } \\
\text { Do rules require an external body to } \\
\text { periodically audit the SWF's annual } \\
\text { financial reports? }\end{array}$ & 100 & $\begin{array}{l}\text { According to the article } 22 \text { of } \\
\text { HDFL, the external auditing } \\
\text { required at least once a year. The } \\
\text { auditing result should be reported to } \\
\text { the parliament. }\end{array}$ \\
\hline d) & $\begin{array}{l}\text { SWF legislative review requirement } \\
\text { Is the legislature required to review the } \\
\text { SWF's annual financial reports? }\end{array}$ & 25 & $\begin{array}{l}\text { There is no specific regulation } \\
\text { about requirement to review the } \\
\text { annual financial reports. According } \\
\text { to law of government special funds } \\
\text { parliament standing committee has } \\
\text { right to discuss the report if it is } \\
\text { necessary. }\end{array}$ \\
\hline 2.3.6 & \multicolumn{3}{|l|}{ SWF Financial Reporting Practice } \\
\hline a) & $\begin{array}{l}\text { SWF financial report disclosure } \\
\text { Does the SWF publicly disclose its annual } \\
\text { financial reports? }\end{array}$ & 0 & $\begin{array}{l}\text { There is no financial report } \\
\text { published through public media. }\end{array}$ \\
\hline b) & $\begin{array}{l}\text { SWF financial audit timeframe } \\
\text { Were there annual financial reports } \\
\text { audited over the most recently completed } \\
\text { audit timeframe? }\end{array}$ & 50 & $\begin{array}{l}\text { There are two audit reports publicly } \\
\text { disclosed }^{27}\end{array}$ \\
\hline c) & $\begin{array}{l}\text { SWF legislative review } \\
\text { From } 2015 \text { onwards, has the legislature } \\
\text { reviewed the SWF's annual financial } \\
\text { reports? }\end{array}$ & 0 & $\begin{array}{l}\text { There is publicly disclosed } \\
\text { documents about legislature to } \\
\text { reviewed the annual financial } \\
\text { reports. }\end{array}$ \\
\hline & Overall average score & 53 & \\
\hline
\end{tabular}

Table 2. Resource Governance Index - SWF management (NRGI, 2017) ${ }^{27}$

27 National Audit Authority's report in 2017. https://www.audit.mn/wp-content/uploads/2017/05/hunii-hogjil-san.pdf National Audit Authority's report regarding the HDF's revenue and expenditure in 2014. http://www.audit.gov.mn/ files/report/compliance/hugjil-san.pdf 
According to RGI the FSF got are important elements to determine the 42 scores, the HDF evaluated same resource governance. Other components method and got 53 score. It illustrates of resource governance such as enabling that the HDF is more efficient than the environment and value realization FSF. This score does not illustrate the relatively static. The evaluation score resource governance because it covers of the HDF and FSF shows higher only the management of SWF questions. performance compared to Truman However, the evaluation of the HDF scoreboard. (also FHF) will fulfill the examination of overall SWF's management, and these

\section{Conclusion}

The overall the Mongolian SWFs it does not show the causal reason of have been performing inefficiently according to assessment of SWF using RGI, Truman scoreboard and LMTI. There were some limits accessing data related to the SWFs, on other hand this situation illustrates the transparency and accountability of the SWFs. Also, these evaluation methods assess the SWF according to published regulations and availability of reports. In other words, it can exhibit the strength of regulation and level of transparency, otherwise mismanagement.

The case study of politic and economic situation of Mongolia helped to find the causal reason of mismanagement of SWFs. The result shows that the government over optimistic view of economic situation and political promises lead to mismanagement of SWFs. In addition, Mongolia has relatively good regulation regarding the SWFs, but the government's commitment is very poor following regulation. 